\title{
Molecular research and the control of Chagas disease vectors
}

\author{
FERNANDO ABAD-FRANCH ${ }^{1,2}$ and FERNANDO A. MONTEIRO ${ }^{3}$ \\ ${ }^{1}$ Coordenação de Biodiversidade em Saúde, Entomologia Médica, Centro de Pesquisa Leônidas e Maria Deane \\ Fiocruz-Amazônia, Rua Terezina 476, Adrianópolis, 69057-070 Manaus, AM, Brasil \\ ${ }^{2}$ Pathogen Molecular Biology Unit, Department of Infectious and Tropical Diseases \\ London School of Hygiene and Tropical Medicine, Keppel St., London WC1E 7HT, United Kingdom \\ ${ }^{3}$ Departamento de Medicina Tropical, Instituto Oswaldo Cruz, Fiocruz, \\ Av. Brasil 4365, 21045-900 Rio de Janeiro, RJ, Brasil
}

Manuscript received on March 3, 2005; accepted for publication on March 30, 2005; presented by Lucia Mendonça Previato

\begin{abstract}
Chagas disease control initiatives are yielding promising results. Molecular research has helped successful programs by identifying and characterizing introduced vector populations and by defining intervention targets accurately. However, researchers and health officials are facing new challenges throughout Latin America. Native vectors persistently reinfest insecticide-treated households, and sylvatic triatomines maintain disease transmission in humid forest regions (including Amazonia) without colonizing human dwellings. In these scenarios, fine-scale vector studies are essential to define epidemiological risk patterns and clarify the involvement of little-known triatomine taxa in disease transmission. These eco-epidemiological investigations, as well as the planning and monitoring of control interventions, rely by necessity on accurate taxonomic judgments. The problems of cryptic speciation and phenotypic plasticity illustrate this need - and how molecular systematics can provide the fitting answers. Molecular data analyses also illuminate basic aspects of vector evolution and adaptive trends. Here we review the applications of molecular markers (concentrating on allozymes and DNA sequencing) to the study of triatomines. We analyze the suitability, strengths and weaknesses of the various techniques for taxonomic, systematic and evolutionary investigations at different levels (populations, species, and higher taxonomic categories).
\end{abstract}

Key words: molecular systematics, DNA, allozymes, Triatominae, Chagas disease.

\section{CHAGAS DISEASE: BURDEN, CONTROL EFFORTS AND NEW CHALLENGES}

Chagas disease (CD), caused by Trypanosoma cruzi and transmitted by triatomine bugs, is a major public health problem in Latin America. An overall prevalence of $\sim 18$ million infections was estimated in

Dedicated to the memory of Prof. Dr. Herman Lent by initiative of Pedro L. Oliveira, Instituto de Bioquímica Médica. Universidade Federal do Rio de Janeiro (UFRJ), RJ, Brasil. Correspondence to: Fernando A. Monteiro

E-mail: fam@ioc.fiocruz.br the late 1980s, with 90 million people living at risk and 45000 deaths/year. CD was the most important parasitic disease in Latin America in terms of its impact on national economies and public health systems (WHO 1991, 2002, World Bank 1993, Miles et al. 2003).

In the absence of vaccines or adequate drugs for large-scale treatment, the reduction of disease burden critically depends on the control of transmission by triatomine vectors and infected blood transfusion. Several multinational initiatives have been launched 
with that purpose. Ten years of concerted action in the Southern Cone have resulted in the elimination of transmission by Triatoma infestans (the most widespread domestic vector) from vast areas of the region. Incidence dropped by an average of $94 \%$ in the area, and by $65 \%$ in Latin America (WHO 2002). Recent estimates show however that substantial efforts are still necessary: overall prevalence remains over 12 million, with 200000 new cases/year in 15 countries (Morel and Lazdins 2003).

The success of the Southern Cone initiative was eased by the fact that the main vector species, $T$. infestans, is entirely domestic throughout most of its range, making reinfestation of insecticide-treated houses rare (Dias and Schofield 1999). Other initiatives (Andean Countries, Central America, Mexico, and Amazonia), launched after 1997, face distinct epidemiological situations. General trends are encouraging in that vector control programs are now active (and screening of blood donations is mandatory) in all endemic countries.

Recent studies have nonetheless revealed new eco-epidemiological scenarios posing further challenges to the control of Chagas disease. In areas were autochthonous vectors are synanthropic (e.g., T. brasiliensis in NE Brazil, T. dimidiata in Mesoamerica, or $R$. prolixus in Venezuela), longitudinal vigilance is required for the detection and spraying of reinfested dwellings (Ramsey and Schofield 2003). In the Amazon and in other humid forest regions, vector-borne transmission occurs without household colonization when sylvatic bugs invade houses or contaminate food-processing equipment. The design of adequate control strategies for those areas demands innovative approaches and will require substantial research efforts (Coura et al. 2002, Dias et al. 2001, Guhl and Schofield 2004).

In these newly recognized contexts, fine-scale studies on vector biology, ecology and behavior are essential to define epidemiological risk patterns and clarify the involvement of little-known triatomine taxa in disease transmission. Reliable taxonomic identification is obviously the keystone of any of these investigations.

\section{THE TAXONOMY AND SYSTEMATICS OF THE TRIATOMINAE: MORPHOLOGY-BASED APPROACHES}

Most triatomine species can be confidently identified by their external morphological-chromatic characters (Lent and Wygodzinsky 1979, Carcavallo et al. 1997a, 1999). Some groups are however problematic, with a few of them being essentially isomorphic; others present high levels of phenotypic plasticity (resulting in either convergence or divergence) that can confound taxonomic assignations (Lent and Wygodzinsky 1979, Dujardin et al. 1999b). Moreover, species descriptions based on one or a few type specimens overlook intraspecific variation, adding uncertainty in many cases.

Complementary qualitative techniques include the study of male genitalia (e.g., Jurberg 1996), cuticular structures (e.g., Carcavallo et al. 1997b), antennal sensilla (e.g., Catalá 1997) or eggshell structure (e.g., Barata 1998).

Quantitative phenotypic analyses regard the patterns of variability and similarity revealed by metric analyses as a reflection of underlying genetic relationships. Morphometric techniques based on discriminant analyses are used in the surveillance of reinfestation of sprayed dwellings and in the study of phenotypic changes linked to microhabitat adaptations. Morphometric analyses may also be used to explore phylogenetic relationships among closely related entities. However, the partitioning of environment-related metric variance is problematic, obscuring the interpretation of results in terms of kinship (cf. Dujardin et al. 2002, Patterson 2002).

Phylogenetic analyses of morphological characters have traditionally (and efficiently) made use of Hennigian cladistics. Within the Triatominae however, only two cladograms (on Panstrongylus and the Bolboderini, both lacking explicitness of character polarization) have ever been published (Lent and Wygodzinsky 1979).

Faced with the difficulties of (1) taxonomic assignation, at least within problematic groups, and (2) establishment of systematic/evolutionary relationships (which affect several epidemiologically 
important taxa), researchers have turned to molecular approaches in an attempt to clarify the taxonomic status, systematic relationships, and evolution of the Triatominae.

\section{MOLECULAR RESEARCH ON TRIATOMINES}

Molecular analyses have revolutionized biological sciences; among the many applications, the definition of molecular markers for the distinction of biological entities and the assessment of their systematic and evolutionary relationships are particularly widespread.

Vector control programs are already benefiting from knowledge derived from molecular research. Major contributions have been the identification and characterization of introduced vector populations (e.g., R. prolixus in Central America or T. infestans in many Southern Cone countries; Dujardin et al. 1998a, Panzera et al. 2004) and the accurate definition of control intervention targets (e.g., R. prolixus as a valid entity separate from $R$. robustus, and chromatic forms of $T$. brasiliensis constituting distinct species; Monteiro et al. 2003, 2004). Crucial questions often lay within the range of fine-grained systematics (i.e., that of intraspecific variation), but the assessment of interspecific variability and systematic/evolutionary relationships is important in many cases as it may allow for broader extrapolations regarding epidemiologically relevant groups (Schaefer 2003).

Here we present an overview of the use of molecular markers in triatomine research. We also comment on the applicability, strengths and weaknesses of the main molecular techniques (Tables I and II), give suggestions for future research, and highlight important issues to be considered during research planning and experimental design (Table III).

We lay emphasis on the idea that correct identification of the bugs is crucial for a trustworthy understanding of vector biology. All ecological, behavioral, physiological, epidemiological or evolutionary investigations, as well as the planning and mon- itoring of control interventions, rely by necessity on accurate taxonomic judgments. At the same time, the analysis of molecular datasets illuminates more basic questions concerning the kinship, evolution, and adaptive trends of the vectors. We consider the use of different techniques for the analysis of genetic material (from caryotyping to DNA sequence analysis) and gene products (mainly allozymes) in the study of populations, species, and deeper phyletic clades within the Triatominae. We concentrate on those methods that have yielded a greater wealth of information, and especially on those that produced key knowledge for the design of rational disease control strategies.

\section{AlloZyme EleCtrophoresis}

The analysis of the electrophoretic properties of allozymes (enzymes with identical function but distinct electrophoretic migration patterns encoded by different alleles of the same locus) has been extensively applied to the study of Triatominae. This approach has for decades represented the first choice to examine the molecular taxonomy and evolutionary relationships of many different organisms, including insects (Thorpe and Solé-Cava 1994, Loxdale and Lushai 1998, Dujardin et al. 2002). Intraspecific level analyses allow for (1) the assessment of the degree of genetic variability within a species or population (as the expected number of heterozygous individuals across loci $-\mathrm{He}$ ), for (2) the detection of within-population departures from the Hardy-Weinberg [H-W] equilibrium (through the observation of the excess or deficit of heterozygotes $-F_{\text {IS }}$ ), and (3) for the estimation of levels of genetic structuring (measured as the differentiation between populations based upon the interpopulation component of the total genetic variation $-F_{\mathrm{ST}}$ ). Finally, (4) rates of gene flow (i.e. migration) between putative populations can be estimated (Thorpe and Solé-Cava 1994, Frías and Dujardin 1996, Loxdale and Lushai 1998, Dujardin et al. 2002).

Allozymes are adequate markers for the study of intraspecific variation in most insect vector groups (Loxdale and Lushai 1998). However, triatomines 
TABLE I

Applicability of often-used molecular techniques to problems in systematics. Modified from Hillis et al. (1996).

\begin{tabular}{l|c|c|c|c|c|c}
\hline & Allozymes & Cytogenetics & PCR-RFLP & RAPD & Microsatellites & $\begin{array}{c}\text { DNA } \\
\text { sequencing }\end{array}$ \\
\hline Heterozigosity & + & - & $\approx$ & - & + & $+(\$)$ \\
\hline Population subdivision & + & $\approx$ & $\approx$ & $\approx$ & + & $+(\$)$ \\
\hline Geographic variation & + & $\approx$ & + & - & + & $+(\$)$ \\
\hline Species boundaries & + & + & + & + & + & + \\
\hline Phylogeny & $\approx$ & - & $\approx$ & - & - & + \\
\hline
\end{tabular}

Key: - , inappropriate use of technique; $\approx$, marginally appropriate or appropriate under limited circumstances; $+(\$)$, appropriate but expensive; + , appropriate and effective method.

in particular tend to present very low levels of allozyme variability (i.e. polymorphic loci), which poses certain limitations to the use of this marker for population level studies. Nevertheless, some studies have succeeded in finding enough variation to allow for inferences on population structure to be made.

T. infestans populations, for instance, are panmictic within Andean villages in Bolivia and Peru, but strongly structured (and conforming to a model of isolation by distance) among localities. Analysis of allelic frequencies allowed for the definition of the probable area of origin of $T$. infestans (Dujardin et al. 1998b). Further studies indicated that structuring within localities was also present, suggesting that the basic population unit is represented by individual households (Breniére et al. 1998). Using a similar approach, Noireau et al. (1999b) showed that the panmictic unit of Bolivian populations of T. sordida (allozymic group 1) is larger than that reported for T. infestans, with departures from $\mathrm{H}$ $\mathrm{W}$ equilibrium detected only between populations located over $\sim 20 \mathrm{~km}$ apart; this suggested a better dispersal capacity than previously thought for $T$. sordida (Noireau et al. 1999b).

Moreover, low levels of allozyme diversity in Triatominae have been regarded as a possible indication of higher vulnerability to chemical control as insecticide resistance would be less likely to emerge in genetically depauperate insecticide-treated populations (Schofield et al. 1995, Guhl and Schofield
1996, Schofield and Dujardin 1997, Dujardin et al. 1998a, 2002, Monteiro et al. 2001).

In taxonomy (or alpha systematics, i.e. species identification), allozyme electrophoresis is used for the distinction of cryptic species and the determination of the correct status of dubious populations. Detection of reproductive isolation between populations of two (or more) cryptic species is particularly easy when populations are sympatric. This is because the rationale 'if the populations belong to the same gene pool they must be exchanging genes' can be used as the null hypothesis. Thus, if loci are scored that present different alleles fixed for both populations (i.e., they are diagnostic), the null hypothesis is rejected in favor of the alternative hypothesis of the existence of more than one taxon occurring in that area (for more details see Thorpe and Solé-Cava 1994).

This reasoning cannot be applied to allopatric populations, among which gene exchange might be absent simply due to geographical separation. These cases require the comparison of pairwise genetic distance values between the putative populations with those from the literature. This approach also works well because, provided enough individuals and loci are surveyed, genetic distances are usually much higher between populations of closely related species than between conspecific populations.

Cut-off values of genetic distance $(D$, Nei 1972) for species distinction have been proposed as 
TABLE II

Strengths and weaknesses of major molecular approaches applied to vector systematics.

\begin{tabular}{|c|c|c|}
\hline Method & Strengths & Weaknesses \\
\hline Allozymes & $\begin{array}{l}\text { - established marker } \\
\text { - relatively inexpensive } \\
\text { - co-dominant marker } \\
\text { - provides information } \\
\text { on several loci (and } \\
\text { individuals) simultaneously }\end{array}$ & $\begin{array}{l}\text { - samples must be fresh or frozen } \\
\text { - some gels can be difficult to } \\
\text { genetically score } \\
\text { - requires considerable practice }\end{array}$ \\
\hline Cytogenetics & $\begin{array}{l}\text { - relatively inexpensive } \\
\text { and simple technique } \\
\text { - may be informative on } \\
\text { recent range expansion } \\
\text { processes }\end{array}$ & $\begin{array}{l}\text { - often too conserved for } \\
\text { comparison of closely related taxa } \\
\text { - live specimens required }\end{array}$ \\
\hline PCR-RFLP & $\begin{array}{l}\text { - established marker } \\
\text { - relatively inexpensive } \\
\text { - co-dominant marker }\end{array}$ & $\begin{array}{l}\text { - might reveal little polymorphism } \\
\text { - partial digestion can lead to } \\
\text { problems } \\
\text { - gives information on one locus } \\
\text { at a time }\end{array}$ \\
\hline RAPD & $\begin{array}{l}\text { - inexpensive } \\
\text { - fast execution } \\
\text { - requires small amount of } \\
\text { molecular equipment and } \\
\text { reagents } \\
\text { - provides information on } \\
\text { several loci (and individuals) } \\
\text { simultaneously }\end{array}$ & $\begin{array}{l}\text { - often presents reproducibility } \\
\text { problems } \\
\text { - dominant marker } \\
\text { - interpretation is subjective } \\
\text { - little guarantee of homology } \\
\text { among co-migrating bands }\end{array}$ \\
\hline Microsatellites & $\begin{array}{l}\text { - highly polymorphic (much } \\
\text { more than allozymes) } \\
\text { - co-dominant markers } \\
\text { - provides information on } \\
\text { several loci (and individuals) } \\
\text { simultaneously }\end{array}$ & $\begin{array}{l}\text { - development of primers can be } \\
\text { time- (and money-) consuming } \\
\text { - requires access to sequencer }\end{array}$ \\
\hline DNA sequencing & $\begin{array}{l}\text { - highly informative } \\
\text { - interpretation is objective } \\
\text { - allows for studies on any } \\
\text { taxonomic level } \\
\text { - allows for the comparison } \\
\text { of results among different labs } \\
\text { through DNA databanks }\end{array}$ & $\begin{array}{l}\text { - labor-intensive } \\
\text { - reagents are expensive } \\
\text { - must have access to a sequencer } \\
\text { - gives information on a single } \\
\text { locus }\end{array}$ \\
\hline
\end{tabular}

$D \approx 0.16$ (Thorpe and Solé-Cava 1994). In medically important insects, $D$ values $>0.1$ are considered to indicate specific rank (Noireau et al. 1998). In triatomines, mean $D$ values of $0.504 \pm 0.341$ have been scored in 30 interspecific comparisons, while conspecific populations (142 comparisons) were separated by mean $D=0.013 \pm 0.009$ (Dujardin et al. 2002). 
TABLE III

Main areas of study, suggestions for future research, and requirements (and cautions) to be considered during research planning and experimental design.

\begin{tabular}{|c|c|c|c|}
\hline Field of study & Subjects & Examples & Requirements and cautions \\
\hline $\begin{array}{l}\text { Population } \\
\text { genetics }\end{array}$ & $\begin{array}{l}\text { Dispersion-migration and } \\
\text { gene flow; speciation; } \\
\text { hybridization }\end{array}$ & $\begin{array}{l}\text { Populations of main vectors } \\
\text { in their areas of origin - } \\
\text { mainly assessment of gene } \\
\text { flow between sylvatic and } \\
\text { domestic populations (e.g., } \\
\text { Rhodnius prolixus in } \\
\text { Venezuela) }\end{array}$ & $\begin{array}{l}\text { Adequate sampling, with } \\
\text { use of field-collected } \\
\text { specimens; use of fast } \\
\text { evolving markers; } \\
\text { richness of associated } \\
\text { ecological data }\end{array}$ \\
\hline Taxonomy & $\begin{array}{l}\text { Sibling species and } \\
\text { species complexes; } \\
\text { synonyms; rapid } \\
\text { species/populations } \\
\text { diagnosis }\end{array}$ & $\begin{array}{l}\text { Sibling species within } \\
R \text {. robustus or Triatoma } \\
\text { dimidiata; chromatic variants } \\
\text { in Panstrongylus and } \\
\text { Triatoma }\end{array}$ & $\begin{array}{l}\text { Wide sampling to account } \\
\text { for intraspecific variation; } \\
\text { use more than one } \\
\text { marker; obtain } \\
\text { controversial forms, or } \\
\text { taxa, in sympatry } \\
\text { (whenever possible) }\end{array}$ \\
\hline $\begin{array}{l}\text { Phylogenetic } \\
\text { relationships }\end{array}$ & $\begin{array}{l}\text { Monophyly/non- } \\
\text { monophyly of the } \\
\text { subfamily and of } \\
\text { other major groups } \\
\text { (tribes, genera); } \\
\text { phylogeography - } \\
\text { historical biogeography; } \\
\text { relationships among } \\
\text { members of problematic } \\
\text { groups }\end{array}$ & $\begin{array}{l}\text { Address relationships between } \\
\text { members of: (1) Little-known } \\
\text { tribes (Cavernicolini, } \\
\text { Bolboderini, Alberproseniini); } \\
\text { (2) Triatoma of North (vs.) } \\
\text { South America; (3) } \\
\text { Panstrongylus-Triatoma (and } \\
\text { Meccus); (4) Old World } \\
\text { species; (5) trans-Andean } \\
\text { Rhodnius species; (6) little- } \\
\text { known species groups (e.g., } \\
\text { dispar complex, Mepraia, } \\
\text { Eratyrus); (7) groups of } \\
\text { species including the main } \\
\text { vectors of Chagas disease; (8) } \\
\text { geographical forms of widely } \\
\text { distributed species (e.g., } \\
\text { P. geniculatus, } \\
\text { P. rufotuberculatus) }\end{array}$ & $\begin{array}{l}\text { Selection of markers and } \\
\text { of adequate analytical } \\
\text { methods; taxon sampling, } \\
\text { including the designation } \\
\text { of suitable outgroups; } \\
\text { area sampling in the case } \\
\text { of widely distributed } \\
\text { species }\end{array}$ \\
\hline $\begin{array}{l}\text { Ecology and } \\
\text { adaptive } \\
\text { trends }\end{array}$ & $\begin{array}{l}\text { Ecological/evolutionary } \\
\text { adaptations; phenotypic } \\
\text { plasticity }\end{array}$ & $\begin{array}{l}\text { Adaptive consequences of } \\
\text { domestication in primary and } \\
\text { secondary vectors; } \\
\text { phenotypic-behavioral } \\
\text { changes along ecological } \\
\text { gradients }\end{array}$ & $\begin{array}{l}\text { Combine molecular data } \\
\text { with rich ecological } \\
\text { datasets and quantitative } \\
\text { phenotypic assessment }\end{array}$ \\
\hline
\end{tabular}


In general, when clear differences (diagnostic loci in sympatry or large genetic distances in allopatry) were detected between populations, the usual outcome was that more than one taxon was involved, either because of misidentification (e.g., R. colombiensis wrongly identified as $R$. prolixus) or cryptic speciation (as with $T$. sordida) (Moreno et al. 1999, Noireau et al. 1998, respectively). The characterization of phenotypically diverse populations of $T$. brasiliensis seemed to represent an exception in that fixed allozyme differences were found between conspecific populations (Costa et al. 1997). The alternative view that several distinct taxa were involved was later supported by DNA sequence analysis (Monteiro et al. 2004).

Several examples illustrate the use of allozymes in the assessment of triatomine taxonomy. The absence of fixed allozyme differences between $R$. prolixus (a major disease vector) and $R$. robustus (sylvatic and of comparatively minor medical importance) from Venezuela led to the suggestion that they were a single taxon (Dujardin et al. 1991, Harry et al. 1992a, b, Harry 1993, Solano et al. 1996). An allozyme comparison of $R$. prolixus and $R$. robustus individuals whose identity was previously confirmed by mitochondrial DNA again revealed no differences. This was interpreted as an indication of recent divergence rather than conspecificity (Monteiro et al. 2002). In similar cases, allozymes revealed negligible differentiation between closely related species within the phyllosoma and oliveirai complexes (Flores et al. 2001, Noireau et al. 2002).

T. sordida, T. garciabesi, T. guasayana and $T$. patagonica are very similar but display distinct synanthropic trends; their overlapping ranges and high intraspecific anatomical variability make specific determination complicated (Gorla et al. 1993). Allozyme electrophoresis confirmed sordida, guasayana and patagonica as valid taxa, and led to the revalidation of $T$. garciabesi and the discovery of two cryptic species within $T$. sordida (García et al. 1995, Panzera et al. 1997, Jurberg et al. 1998, Noireau et al. 1998). The specific identity of $T$. petrochii was likewise confirmed using allozymes
(Monteiro et al. 1998).

Finally, allozyme-based identification of fieldcollected specimens (including nymphs) has been instrumental for meticulous eco-epidemiological investigations. After defining allozyme markers for various species and populations, Noireau and colleagues thoroughly investigated the ecotopes, behavior, and epidemiological significance of several Bolivian triatomines (Noireau et al. 1998, 1999a, 2000a, b, Noireau and Dujardin 2001). A major discovery was that sylvatic foci of T. infestans are much more widespread than previously thought, extending from the Andean highlands well into the Chaco (Noireau et al. 2005).

The evolutionary interpretation of allozyme data has been done based on the relatively straightforward relationships between zymograms and genes. Phylogenetic relationships may be explored by comparing measures of genetic distance derived from allele frequencies (e.g., Nei 1972). Cladistic analyses rely on the ability to identify primitive (plesiomorphic) and derived (apomorphic) character states in the dataset by comparing the ingroup with a suitable sister taxon (or outgroup); only characters that are shared and derived (synapomorphic) are used for phylogenetic inference purposes (Avise 1994, Thorpe and Solé-Cava 1994). Based on these premises, the phylogenetic relationships of several triatomine groups have been explored using allozymes. These studies usually involved assessment of genetic distances among a few, closely related species (e.g. García et al. 1995, Pereira et al. 1996b, Solano et al. 1996, Panzera et al. 1997, Flores et al. 2001), but more complete investigations have been conducted with members of the tribe Rhodniini. Using phenetic techniques, three main clusters were identified within the genus Rhodnius: one basal clade (pallescens (ecuadoriensis-colombiensis)) and two sister groups (prolixus (nasutusneglectus)) and (stali (pictipes-brethesi)) (Chávez et al. 1999). Most of these relationships were confirmed by a cladistic analysis, but a group (brethesi (pictipes-stali)) appeared in a basalmost position in the cladogram; the position of Psammolestes core- 
odes within the tribe could not be satisfactorily resolved (Dujardin et al. 1999a). Recently the phylogeny of the Rhodniini was studied using 12 enzyme loci. Distance analysis produced a dendrogram showing paraphyly of Rhodnius, with Psammolestes tertius as a sister group to the prolixus group within the cluster (domesticus (Ps. tertius (nasutus-neglectus) (prolixus-robustus))). A second main cluster was comprised of (pictipes (brethesi (pallescens-ecuadoriensis))) (Monteiro et al. 2002).

\section{DNA-BASEd Methods}

The use of DNA approaches for the study of triatomine bugs has a short, albeit rather dynamic, history. Molecular studies have provided new insights into the systematics and evolutionary trends of the subfamily, with surveys ranging from inter-tribe to intra-specific levels. Both nuclear and mitochondrial gene sequence polymorphisms have been surveyed. Many of the results have been used to refine and improve disease control strategies throughout Latin America, and will likely prove crucial for the study of secondary vectors as well. Several DNAbased techniques have been hitherto applied to triatomines (Beard and Lyman 1999, Monteiro et al. 2001). These include randomly amplified polymorphic DNA (RAPD) (Carlier et al. 1996, Dujardin et al. 1998a, García et al. 1998, Noireau et al. 2000a, Borges et al. 2000, 2005, Jaramillo et al. 2001, Pacheco et al. 2003), species-specific length variation of rDNA amplicons (Jaramillo et al. 2001), single strand conformational polymorphism analysis (Stothard et al. 1998), sequencing of selected nuclear (Monteiro et al. 2000, Bargues et al. 2000, 2002, Marcilla et al. 2000, 2001, 2002) and mitochondrial gene fragments (García and Powell 1998, Stothard et al. 1998, Lyman et al. 1999, Monteiro et al. 1999, 2000, 2003, 2004, García et al. 2001, 2003, Gaunt and Miles 2002, Hypša et al. 2002, Sainz et al. 2004), and characterization of polymorphic microsatellite markers (Harry et al. 1998, Anderson et al. 2002, García et al. 2004).

\section{DNA SEquenCing}

Sequencing of selected genomic fragments allows for the direct assessment of DNA polymorphisms, providing researchers with the ultimate information for phylogenetic inference and evaluation of kinship among organisms and populations. Different segments of the mitochondrial ( $\mathrm{mt}$ ) and nuclear genome evolve at different rates. Fast-evolving regions are suitable for the study of closely related organisms, whereas conserved sections are more appropriate for comparisons among more diverged taxa ( $\mathrm{Li}$ and Graur 1991, Avise 1994, Hillis et al. 1996, Page and Holmes 1998).

\section{Mitochondrial genes}

Mitochondria are cytoplasmic organelles of eukaryotic cells; they are involved in key physiological and pathologic processes (Avise 1994, Page and Holmes 1998, Saccone et al. 2000). In metazoans, each mitochondrion has a single DNA molecule, 15-20 kilobases in length and containing genes coding for 2 rRNAs, 22 tRNAs, and 13 mRNAs responsible for the synthesis of cell respiration proteins. This same gene composition is found in the only mitochondrial genome of a triatomine sequenced to date (that of Triatoma dimidiata). When compared to those of other insects, the $17019 \mathrm{bp}$-long $T$. dimidata $\mathrm{mt}$ genome has a lower adenine + thymine composition bias (69.5\% A+T) (Dotson and Beard 2001).

The single, circular mtDNA molecule, present in multiple copies $\left(\sim 10^{2}-10^{4}\right.$ per cell), is maternally inherited, replicates with no recombination, and presents faster evolution rates than the nuclear genome (Avise 1994, Saccone et al. 2000). High substitution rates are in part due to defective repair mechanisms during replication, and affect preferentially some parts of the molecule (e.g., degenerate third codon positions in protein-coding genes). Functional and structural constraints lower substitution rates in other sections (e.g., second codon positions) (Avise 1994, Simon et al. 1994, Saccone et al. 2000). At low levels of divergence (up to $\sim 3$ million years) mtDNA substitutions accumulate at 
a constant rate of $\sim 2.3 \%$ pairwise sequence divergence per million years (my) in various arthropod taxa (Brower 1994). A global estimate for animal mtDNA is of $\sim 2 \%$ divergence/my (Avise 1994).

Mitochondrial genes are widely used in population genetics and in evolutionary studies at different levels of divergence. Nucleotide sequence polymorphisms of rapidly evolving mtDNA genes are suitable for the assessment of relationships among recently diverged taxa (Avise 1994, Simon et al. 1994, Page and Holmes 1998). At higher levels of divergence, variable sites are prone to accumulate multiple substitutions (especially transitional hits at third codon positions), and thus become saturated. Saturation erases phylogenetic signal and is a major cause of homoplasy. Further cautions regarding the interpretation of mtDNA results in the study of closely related taxa include the possibility of introgression in hybrid zones (generally detectable by using complementary data from nuclear loci) and the retention of ancestral polymorphisms (or incomplete lineage sorting). On the other hand, direct sequencing is easier than it is with nuclear gene fragments, and sequence alignment is usually straightforward.

In 1999, FA Monteiro et al. reported the first survey of mtDNA sequence polymorphisms (cytochrome $b$ [cyt $b$ ] gene) among populations of a triatomine vector species, $T$. infestans (Monteiro et al. 1999). Results revealed that T. melanosoma and the sylvatic dark morphs of $T$. infestans are phenotypic variants of $T$. infestans. Small but consistent differences were found between Bolivian populations and those from Argentina and Brazil. Within Bolivia, all Andean bugs had identical haplotypes, whereas dark morphs from the Chaco lowlands had slightly divergent sequences. These dark morphs differ from Andean T. infestans in their phenotypes and in ecological features (they are melanic and occupy hollow trees in the Chaco). Allozymes, cytogenetics, interbreeding patterns, RAPDs, and mtDNA all supported the idea of a single species (Noireau et al. 1997, 2000a, Monteiro et al. 1999). Using two mtDNA fragments combined (12S+16S rDNA, totaling $878 \mathrm{bp}$ ), higher levels of sequence diversity were found among geographic populations of $T$. infestans from Argentina. Results showed a pattern of restricted gene flow, and suggested local population recovery from survivors after insecticide spraying. Heteroplasmy (individuals presenting more than one $\mathrm{mt}$ haplotype) was revealed in $15 \%$ of the specimens analyzed (García et al. 2003).

A recent mt cyt $b$ study involving all known chromatic variants of $T$. brasiliensis showed that the juazeiro and melanica forms most likely deserve the status of species. T. b. brasiliensis and T. b. macromelasoma (very different from juazeiro and melani$c a$ ) seem to represent distinct evolutionary lineages. However, because they differ only slightly from each other, a sound taxonomic decision will only be possible when further information is analyzed (Monteiro et al. 2004).

MtDNA sequence analysis revealed that $T$. $d i$ midiata populations from Yucatan are strongly divergent (perhaps a sibling species), and that the natural dispersal of the species probably followed a north-to-south route from southern Mexico through Central America, reaching Colombia. Ecuadorian populations however are probably recent derivatives from Honduran-Guatemalan conspecifics, supporting the hypothesis of an artificial introduction of the species to Ecuador and Peru (Marcilla et al. 2001, Abad-Franch 2003, Harris and Beard, personal communication).

Similarly, several populations of $R$. prolixus (Venezuela, Colombia, Honduras, Guatemala, and Brazil) were found to have virtually identical $\mathrm{mt}$ cyt $b$ haplotypes, suggesting recent, artificial dispersal of synanthropic forms (Monteiro et al. 2000, 2003). This conclusion is also supported by metric and RAPD analyses (Dujardin et al. 1998a). On the other hand, high levels of structuring were found among various populations of $R$. robustus, suggesting that the taxon encompasses a complex of at least four sibling species (Monteiro et al. 2003).

In a study of mt cyt $b$ sequence data from five populations of R. ecuadoriensis (four from Ecuador and one from Peru), Abad-Franch et al. (2004) found that Peruvian bugs present a markedly di- 
vergent haplotype, while all Ecuadorian sequences (nine haplotypes) were similar. The results suggested that the two clades represent discrete phylogroups (or even incipient species), and indicate that control programs can target them independently.

MtDNA sequence data have also been used to solve taxonomic questions. The specific status of several problematic taxa was confirmed (as with $R$. prolixus, robustus, nasutus, and neglectus), while previously recognized species were found to be just chromatic variants (e.g., T. infestans and $T$. melanosoma, see above). In several cases, the analyses revealed that a single putative species was in fact composed of more than one sibling taxon (e.g., $T$. dimidiata, T. brasiliensis, $R$. robustus, or R. ecuadoriensis, see above). In a recent mt cyt $b$ analysis, $R$. pallescens was found to be a very variable species, with four moderately divergent haplotypes detected in a small sample. The closely related $R$. colombiensis presented a haplotype that fell within the range of the intraspecific variation of pallescens, suggesting either conspecificity (colombiensis perhaps representing a race or subspecies) or very recent divergence (Abad-Franch et al. 2003). In a different case, sequencing of a single specimen (identified as $R$. robustus and belonging to a population frequently collected from palm trees in the Ecuadorian Amazon) revealed a cyt $b$ haplotype not found in any other species of Rhodnius. Phylogenetic analyses show that this specimen surprisingly represents the most basal taxon of the robustus lineage (including $R$. prolixus, neglectus, the four sibling robustus, and Psammolestes) (Abad-Franch 2003). If further studies confirm these preliminary results, a new triatomine species would have been discovered after the results of DNA analysis.

The use of mtDNA for assessing systematic and phylogenetic questions among triatomines began in the mid 90s. An early study showed that the three main genera (Rhodnius, Triatoma and Panstrongylus) are well separated. Two main clades (Rhodniini and Triatomini) were evident, but genetic distances were greater between $R$. pictipes and $R$. prolixus than between Panstrongylus and Triatoma
(Stothard et al. 1998).

The phylogeny of 11 species of the infestans complex plus four others has been explored using $\mathrm{mt}$ $12 \mathrm{~S}$ and $16 \mathrm{~S}$ rRNA and cytochrome oxidase I (COI) genes (García and Powell 1998, García et al. 2001). The close relatedness of $T$. infestans and T. platensis was confirmed, and evidence suggesting mtDNA introgression between these species was found. T. circummaculata and T. rubrovaria appeared within the infestans complex, while P. megistus clustered (with low bootstrap support values) with North American species. T. sordida was close to T. matogrossensis and very different from $T$. guasayana (García et al. 2001).

The mt 16S rRNA and cyt $b$ genes have been used by Lyman et al. (1999). The Rhodniini were well separated from the Triatomini as indicated by a deep divergence between the two tribes. The Triatomini species could be further separated in a Central and North American species group and a South American species group. The placement of P. megistus and Dipetalogaster maxima was uncertain, but both were nested well within Triatoma, an indication of the paraphyletic nature of this genus.

Monteiro et al. (2000) assessed the relationships among several species of Rhodniini, including Rhodnius and Psammolestes. Results confirmed the paraphyly of Rhodnius, with Psammolestes appearing closer to the prolixus clade than this was to the pictipes clade. Parsimony analysis of $1429 \mathrm{bp}$ (including fragments of the mt 16S rRNA, mt cyt $b$, and the nuclear D2 variable region of the 28S rRNA gene) yielded two main clades: ((brethesi-pictipes) (ecuadoriensis-pallescens)) and (Ps. tertius (neivai (domesticus (nasutus (neglectus-prolixus) (robustus-prolixus))))).

Hypša et al. (2002) combined different DNA gene fragments (mostly mitochondrial 16S fragments) to construct a phylogeny including 57 species of Triatominae in nine genera, including Old World Linshcosteus. The deep split between Triatomini and Rhodniini was again confirmed. Most of the current generic subdivisions were not recognized as monophyletic clades. Thus, Panstrongylus, Dipeta- 
logaster, Mepraia, and Linshcosteus all appeared as sister taxa of different "Triatoma" species. The paraphyly of Rhodnius with respect to Psammolestes was also confirmed. Several taxonomic and systematic rearrangements were proposed, but some important questions (such as the apparent non-monophyly of Panstrongylus) were not considered (Hypša et al. 2002).

However, the most important finding of this work, albeit not so well supported (Stevens and Schofield 2003), was the indication that the Triatominae are monophyletic. The observation that the Old World genus Linshcosteus clusters within the Triatomini (with T. rubrofasciata as its sister taxon) clearly rules out the possibility of a separate and independent origin for Linshcosteus. An elucidative discussion on the issue of a mono- or polyphyletic origin of the Triatominae has recently been published by Schaefer (2003).

In a recent work, Gaunt and Miles (2002) used $\mathrm{mt}$ COI sequences and amino acid data to calibrate a mitochondrial molecular clock for various insect orders, including Hemiptera. Their results suggest that the evolutionary split of the ancestors of extant Triatomini (represented by South American species of Triatoma, two Panstrongylus, and Eratyrus mucronatus) and Rhodniini took place over 93 mya, roughly coinciding with the beginning of the separation of South American and African landmasses during the Cretaceous. The paraphyletic nature of Triatoma was apparent in that both Eratyrus and Panstrongylus nested again within representatives of that genus.

\section{Nuclear genes}

Nuclear genomic fragments are generally more conserved than mitochondrial genes. They are therefore better suited for analyses of diversity and relationships above the species level. However, ribosomal RNA spacers such as the internal transcribed spacers (ITSs) can be informative for population analyses (Hillis et al. 1996). These markers have also been used in molecular taxonomic and evolutionary stud- ies on Triatominae. The main concerns with the use of ITS regions in systematics refer to problematic sequence alignment and intragenomic variability.

Apart from the combined analysis of $\mathrm{mt}$ gene fragments with the D2 variable region of the $28 \mathrm{~S}$ rRNA gene mentioned above, the second internal transcribed spacer (ITS-2) of the nuclear rDNA has recently been tested as a molecular marker for populations, species, and phylogenetic relationships in various Triatominae. These comparisons mainly involved Mesoamerican Triatoma species belonging to the phyllosoma complex, some other South American Triatoma, and several species of Panstrongylus; various populations of $T$. infestans and a few Rhodniini have also been analyzed (Marcilla et al. 2000, 2001, 2002).

Phylogenetic analyses of ITS-2 sequence data corroborated important findings based on mtDNA by revealing two major clades within the Triatomini, one comprised of Central and North America species (including T. dimidiata, three species of the phyllosoma complex, T. barberi, and D. maxima) and the second encompassing South American species (T. infestans, T. sordida, T. brasiliensis, and P. megistus). They also confirmed the paraphyly of Rhodnius by showing that $P$. tertius is more closely related to $R$. prolixus than the latter is to R. stali (Marcilla et al. 2001). This analysis was later extended to include several other species of Panstrongylus; the topology of the inferred trees varied slightly, with the main difference referring to the tendency of all Panstrongylus species to cluster together with the Mesoamerican Triatomini, rather than with the South American species (Marcilla et al. 2002). These studies provided evidence suggesting that some taxonomic rearrangements might be necessary within the phyllosoma complex and the genus Panstrongylus. For instance, T. picturata and T. longipennis had identical sequences, and the degree of variability within $T$. dimidiata was larger than that recorded for the rest of phyllosoma species. $P$. lignarius (considered sylvatic) and $P$. herreri (a major disease vector in northern Peru) presented identical ITS-2 sequences in spite of wide geographical 
sampling. They have been recently synonymized by Galvão et al. (2003), a procedure that might also be appropriate for $P$. chinai and $P$. howardi, which are probably chromatic variants of the same species (F Abad-Franch and MD Bargues, unpublished data). The unexpected position of $P$. rufotuberculatus as a sister taxon to the dimidiata-phyllosoma clade, with T. barberi-D. maxima occupying the immediate external branch, was interpreted as a strong indication of the non-monophyly of Panstrongylus (Marcilla et al. 2002).

The $100 \%$ sequence identity between Ecuadorian and Honduran specimens of $T$. dimidiata suggested that the former are recent derivatives of a Mesoamerican population probably introduced by people into western Ecuador in the recent past (Marcilla et al. 2001). Similar conclusions regarding human intervention in the passive dispersal of synanthropic bug populations were drawn from the analysis of ITS-2 sequence variation among T. infestans geographic populations (Marcilla et al. 2000).

The 18S subunit of the nuclear rDNA is much more conserved than ITS- 2 or mt protein-coding genes; in triatomines, the substitution rate seems to approach $1.8 \%$ sequence divergence per 100 million years, up to 55 times slower than ITS-2 (Bargues et al. 2000). These substitution rate estimates were used to calculate the time to common ancestry among various triatomine taxa; under the mentioned hypothesis of an $18 \mathrm{~S}$ rDNA molecular clock, divergence between the ancestors of the Triatomini and Rhodniini would give an estimate of $~ 48.9-64.4$ million years ago (mya) (Palaeocene-Eocene) (Bargues et al. 2000). Estimates of divergence between Meso- and South American species of Triatomini fell between 22.8 and 31.9 mya (18S) and between 19.5 to 34.1 mya (ITS-2), long before the Panama Isthmus linked North and South America in the middle Pliocene ( $\sim 3$ mya, although biogeographical evidence shows that some biotic interchange could have occurred from the late Miocene-early Pliocene, i.e. $\sim 6-7$ mya); these results were interpreted as strong evidence suggesting independent evolutionary origins of both groups, whose common ancestors would have diverged during the Oligocene-Miocene (Bargues et al. 2000; see also Cox and Moore 2000).

\section{Randomly AmPlified Polymorphic DNA (RAPD)}

Amplification of polymorphic DNA with random primers has been used to investigate genetic variability in several medically important insects. In triatomines, diversity among $T$. infestans and $T$. sordida populations was assessed by Carlier et al. (1996). The banding patterns clearly separated both species and discriminated sylvatic and domestic populations of $T$. infestans (Carlier et al. 1996). In a further study on Bolivian T. infestans, RAPD profiles separated two main clusters (Andes and Chaco) and, within each clade, sylvatic and domestic populations (Noireau et al. 2000a). García et al. (1998) found diagnostic RAPD profiles for the pairs $R$. prolixus-robustus and $R$. neglectus-nasutus. Honduran and Colombian populations of $R$. prolixus had population-diagnostic RAPD patterns. Reduced variability among Central American bugs suggested recent human-mediated dispersal of a South American population, prompting the idea that local eradication of the species could be contemplated in Central America (Dujardin et al. 1998a).

Although the resolution of RAPD analysis is much higher than that of allozyme electrophoresis in detecting intraspecific variability, the use of random primers requires extreme caution in order to minimize contamination and problems with reproducibility (Black 1993). Another serious problem with RAPDs is that, because primers anneal randomly, there is little guarantee of homology between co-migrating bands. Even specific conditions used for the preparation of samples and PCR may also affect the results, reducing reliability and reproducibility. Finally, because RAPD markers are dominant, there is no way to determine whether a single band on the gel corresponds to a homozygous or heterozygous individual. This precludes the use of such markers for population genetic studies because conformance to $\mathrm{H}-\mathrm{W}$ expectations cannot be tested (Black 1993, Loxdale and Lushai 1998). 


\section{Microsatellites}

Microsatellites are series of short repetitive motifs [e.g., $(\mathrm{GT})_{\mathrm{n}}$ or $(\mathrm{AT})_{\mathrm{n}}$ ] within nuclear DNA; they are highly polymorphic, neutral, and exhibit Mendelian inheritance and codominance (Jarne and Lagoda 1996). Microsatellites have become the tools of choice for population genetics when other markers do not show an adequate degree of polymorphism. Harry et al. (1998) studied sylvatic populations of $R$. pallescens from Attalea palm trees; six out of the 10 microsatellites evaluated were present in frequencies not different from those expected under H-W equilibrium, suggesting panmixia among palm populations in the area. Amplicons were also obtained using template DNA from R. ecuadoriensis and $R$. prolixus (Harry et al. 1998). More recently, Anderson et al. (2002) identified and characterized eight microsatellite loci from populations of $T$. dimidiata from Mexico, Guatemala and Honduras, and García et al. (2004) have characterized 10 loci for $T$. infestans.

\section{Cytogenetics}

Triatomines have holocentric chromosomes, usually with a diploid complement of $2 \mathrm{n}=20 \mathrm{~A}+\mathrm{XX} / \mathrm{XY}(20$ autosomes plus $\mathrm{XX} \bigcirc$ and $\mathrm{XY} \bigcirc^{\top}$ ). Caryotypes with 18A and 22A are rare. Males of North and Central American species of Triatoma usually present an $\mathrm{X}_{1} \mathrm{X}_{2} \mathrm{Y}$ sex mechanism, while South American species typically present XY. Both Panstrongylus and Eratyrus also present $\mathrm{X}_{1} \mathrm{X}_{2} \mathrm{Y}$. All Rhodniini have a $2 n=20 A+X X / X Y$ diploid complement. Special cytogenetic techniques, such as C-banding and detailed analysis of heterochromatic regions, or the study of the meiotic behavior of male chromosomes, have been used to complement morphological characterization of Triatominae. Applications of these methods range from identification of similar species and detection of intraspecific variability to the investigation of evolutionary relationships at different levels of divergence (reviewed by Dujardin et al. 2002).

\section{CONCLUSIONS}

Different molecular approaches, combining sound sampling strategies with an intelligent choice of markers, can be used to address diverse questions on the biogeography, behavior, taxonomy, evolution, and population structure of triatomines. We have presented an overview of what has already been done in these fields. We also aimed at stimulating further work by proposing new avenues for molecular research, underlining, at the same time, what requirements and cautions apply to the design of the studies. It is by producing high-quality results that molecular research will keep providing the basis for more effective schemes of disease vector control and surveillance.

\section{ACKNOWLEDGMENTS}

Supported by the UNDP/World Bank/WHO TDR Special Program and the ECLAT Network.

\section{RESUMO}

Programas destinados ao controle da doença de Chagas vêm apresentando resultados positivos. Estudos moleculares têm auxiliado programas de controle exitosos através da identificação e caracterização de populações de vetores introduzidas, além da definição precisa das espécies a serem combatidas. Contudo, pesquisadores e autoridades da área de saúde estão enfrentando novos desafios, no âmbito da América Latina. Vetores nativos estão continuadamente re-infestando habitações previamente tratadas com inseticidas, e triatomíneos silvestres estão mantendo ciclos de transmissão da doença em regiões de floresta tropical úmida (incluíndo a Amazônia), sem colonizar habitações humanas. Nessas situações, estudos detalhados dos vetores são essenciais na definição de padrões de risco epidemiológico e no esclarecimento do envolvimento de espécies de triatomíneos pouco conhecidas, na transmissão da doença. Investigações ecoepidemiológicas dessa natureza, assim como o planejamento e monitoramento de intervenções de controle, dependem fortemente de identificações taxonômicas precisas. Problemas decorrentes de especiação críptica e da plasticidade fenotípica, ilustram essa necessidade - e de como a sistemática molecular pode contribuir na geração das respostas necessárias. A análise de dados moleculares 
também auxilia no entendimento de aspectos básicos da evolução e tendências adaptativas dos vetores. Neste artigo, fazemos uma revisão da aplicação de marcadores moleculares (concentrando em isoenzimas e sequenciamento de ADN) no estudo de triatomíneos. Analisamos também a aplicabilidade, vantagens e desvantagens dos métodos mais utilizados, nas investigações em diferentes níveis sistemáticos (populações, espécies e categorias taxonômicas mais elevadas).

Palavras-chave: sistemática molecular, ADN, isoenzimas, Triatominae, doença de Chagas.

\section{REFERENCES}

Abad-Franch F. 2003. The ecology and genetics of Chagas disease vectors in Ecuador, with emphasis on Rhodnius ecuadoriensis (Triatominae). PhD Thesis, London School of Hygiene and Tropical Medicine, University of London, London, UK, 411 p.

Abad-Franch F, Monteiro FA, Patterson JS and MiLes MA. 2003. Phylogenetic relationships among members of the Pacific Rhodnius lineage (Hemiptera: Reduviidae: Triatominae). Infect Genet Evol 2: 244-245.

Abad-Franch F, Monteiro FA, Aguilar VHM and Miles MA. 2004. Population-level mitochondrial DNA sequence diversity in Rhodnius ecuadoriensis. Programme and abstracts, IX European Multicolloquium of Parasitology, Valencia, Spain, 201 p.

Anderson JM, Lai JE, Dotson EM, Cordón-Rosales C, Ponce C, Norris DE and Beard CB. 2002. Identification and characterization of microsatellite markers in the Chagas disease vector Triatoma dimidiata. Infect Genet Evol 1: 243-248.

AvisE JC. 1994. Molecular markers, natural history and evolution. Chapman and Hall, New York, NY, USA, $511 \mathrm{p}$.

BARATA JMS. 1998. Macroscopic and exochorial structures of Triatominae eggs, p. 409-448 in (CARCAvallo RU, GalíndeZ Girón I, JURBERG J AND LENT $\mathrm{H}$ (Eds)), Atlas of Chagas disease vectors in the Americas, Vol. II. Editora Fiocruz, Rio de Janeiro, RJ, Brazil.

Bargues MD, Marcilla JA, Ramsey J, Dujardin JP, Schofield CJ AND Mas-Coma S. 2000. Nuclear rDNA-based molecular clock of the evolution of Triatominae (Hemiptera: Reduviidae), vectors of Chagas disease. Mem Inst Oswaldo Cruz 95: 567-573.
Bargues MD, Marcilla JA, Dujardin JP and MasComa S. 2002. Triatomine vectors of Trypanosoma cruzi: a molecular perspective based on nuclear ribosomal DNA markers. Trans R Soc Trop Med Hyg 96 (Suppl. 1): 159-164.

BeARD CB AND Lyman DF. 1999. DNA-based approaches for inter- and intraspecific analysis of Chagas disease vectors, p. 74-77 in (SCHOFIELD CJ AND Ponce C (Eds)), Proceedings of the second International Workshop on population genetics and control of Triatominae, Tegucigalpa, Honduras, INDRE, Mexico City, Mexico.

BLACK WC $4^{\mathrm{TH}}$. 1993. PCR with arbitrary primers: approach with care. Insect Mol Biol 2: 1-6.

Borges EC, Dujardin JP, Schofield CJ, Romanha AJ And Diotaiuti L. 2000. Genetic variability of Triatoma brasiliensis (Hemiptera: Reduviidae) populations. J Med Entomol 37: 872-877.

Borges EC, Dujardin JP, Schofield CJ, Romanha AJ ANd Diotaiuti L. 2005. Dynamics between sylvatic, peridomestic and domestic populations of Triatoma brasiliensis (Hemiptera: Reduviidae) in Ceará State, Northeastern Brazil. Acta Tropica 93: 119-126.

Breniére SF, Bosseno MF, Vargas F, Yaksic N, Noireau F, Noel S, Dujardin JP and Tibayrenc M. 1998. Smallness of the panmictic unit of Triatoma infestans (Hemiptera: Reduviidae). J Med Entomol 35: 911-917.

BROWER AVZ. 1994. Rapid morphological radiation and convergence among races of the butterfly Heliconius erato inferred from patterns of mitochondrial DNA evolution. Proc Natl Acad Sci USA 91: 6491-6495.

Carcavallo RU, Galíndez Girón I, Jurberg J and LENT H (Eds), 1997a. Atlas of Chagas disease vectors in the Americas, Vol. I. Editora Fiocruz, Rio de Janeiro, RJ, Brazil.

Carcavallo RU, Galíndez Girón i, Catalá S, Jurberg J, Lent H, Galvão C and Barata JMS. 1997b. Some anatomic structures studied with Scanning Electron Microscopy (SEM), p. 299-393 in (Carcavallo RU, Galíndez Girón I, Jurberg J AND LeNT H (Eds)), Atlas of Chagas disease vectors in the Americas, Vol. I. Editora Fiocruz, Rio de Janeiro, RJ, Brazil.

Carcavallo RU, Galíndez-Girón I, Jurberg J AND LENT H (Eds). 1999. Atlas of Chagas disease vectors 
in the Americas, Vol. III. Editora Fiocruz, Rio de Janeiro, RJ, Brazil.

Carlier L, Muñoz M and Dujardin JP. 1996. A RAPD protocol for Triatominae, p. 81-83 in (SCHOFIELD CJ, Dujardin JP AND Jurberg J (Eds)), Proceedings of the International Workshop on population genetics and control of Triatominae, Santo Domingo de los Colorados, Ecuador, INDRE, Mexico City, Mexico.

Catalá S. 1997. Antennal sensilla of Triatominae (Hemiptera: Reduviidae): a comparative study over five genera. Int J Insect Morphol Embryol 228: 6773.

Chávez T, Moreno J And Dujardin JP. 1999. Isoenzyme electrophoresis of Rhodnius species: a phenetic approach to relationships within the genus. Ann Trop Med Parasitol 93: 229-307.

Costa J, Freitas-Sibajev MGR, Marchon-Silva V, Pires MQ ANd Pacheco RS. 1997. Isoenzymes detect variation in populations of Triatoma brasiliensis (Hemiptera, Reduviidae, Triatominae). Mem Inst Oswaldo Cruz 92: 459-464.

Coura JR, Junqueira ACV, Fernandes O, Valente SAS AND Miles MA. 2002. Emerging Chagas disease in Amazonian Brazil. Trends in Parasitology 18: 171-176.

Cox CB And Moore PD. 2000. Biogeography. An ecological and evolutionary approach. Blackwell Science, Oxford, UK, 298 p.

Dias JCP AND SCHOFIEld CJ. 1999. The evolution of Chagas disease (American trypanosomiasis) control after 90 years since Carlos Chagas discovery. Mem Inst Oswaldo Cruz 94 (Suppl. 1): 103-121.

Dias JCP, Vinhaes MC, Silveira AC, Schofield CJ, Cardoso B and Coura JR. 2001. Pesquisas prioritárias sobre doença de Chagas na Amazônia: agenda de curto-médio prazo. Rev Soc Bras Med Trop 34: 497-498.

Dotson EM And BEARD CB. 2001. Sequence and organization of the mitochondrial genome of the Chagas disease vector, Triatoma dimidiata. Insect Mol Biol 10: 205-215.

Dujardin JP, Muñoz M, Chavez T, Ponce C, Moreno J AND SCHOFIELD CJ. 1998a. The origin of Rhodnius prolixus in Central America. Med Vet Entomol 12: 113-115.
Dujardin JP, Schofield CJ AND Tibayrenc M. 1998 b. Population structure of Andean Triatoma infestans: allozyme frequencies and their epidemiological relevance. Med Vet Entomol 12: 20-29.

Dujardin JP, García-Zapata MT, Jurberg J, PoeLants P, Cardozo L, Panzera F, Dias JCP AND SCHOFIELD CJ. 1991. Which species of Rhodnius is invading houses in Brazil? Trans R Soc Trop Med Hyg 85: 679-680.

Dujardin JP, Chávez T, Moreno JM, Machane M, Noireau F ANd Schofield CJ. 1999a. Comparison of isoenzyme electrophoresis and morphometric analysis for phylogenetic reconstruction of the Rhodniini (Hemiptera: Reduviidae: Triatominae). J Med Entomol 36: 653-659.

Dujardin JP, PANZera F ANd SChofield CJ. 1999b. Triatominae as a model of morphological plasticity under ecological pressure. Mem Inst Oswaldo Cruz 94 (Suppl. 1): 223-228.

Dujardin JP, Schofield CJ ANd Panzera F. 2002. Los vectores de la enfermedad de Chagas. Académie Royale des Sciences d'Outre-Mer, Brussels, Belgium, $189 \mathrm{p}$.

Flores A, Magallón-Gastélum E, Bosseno MF, OrdóÑEz R, LOZANo-Kasten F, EsPinOZa B, RAMSEY J AND BRENIÉRE SF. 2001. Isoenzyme variability of five principal triatomine vector species of Chagas disease in Mexico. Infect Genet Evol 1: 21-28.

FríAs D AND DuJARDIN JP. 1996. Detección de la variación genética a nivel poblacional a través de electroforesis de isoenzimas, p. 65-71 in (SCHOFIELD CJ, Dujardin JP AND Jurberg J (Eds)), Proceedings of the International Workshop on population genetics and control of Triatominae, Santo Domingo de los Colorados, Ecuador, INDRE, Mexico City, Mexico.

Galvão C, Rocha DS, Carcavallo RU and Jurberg J. 2003. A checklist of the current valid species of the subfamily Triatominae Jeannel, 1919 (Hemiptera, Reduviidae) and their geographical distribution, with nomenclatural and taxonomic notes. Zootaxa 202: $1-36$.

García AL, Carrasco HJ, Schofield CJ, Valente SAS, Frame IA, Stothard JR and Miles MA. 1998. Random amplification of polymorphic DNA as a tool for taxonomic studies of triatomine bugs (Hemiptera: Reduviidae). J Med Entomol 35: 3845 . 
García BA AND Powell JR. 1998. Phylogeny of species of Triatoma (Hemiptera: Reduviidae) based on mitochondrial DNA sequences. J Med Entomol 35: 232 238.

García BA, Canale DM and Blanco A. 1995. Genetic structure of four species of Triatoma (Hemiptera: Reduviidae) from Argentina. J Med Entomol 32: 134-137.

García BA, Moriyama EN and Powell JR. 2001. Mitochondrial DNA sequences of triatomines (Hemiptera: Reduviidae): phylogenetic relationships. J Med Entomol 38: 675-683.

García BA, Manfredi C, Fichera L and Segura EL. 2003. Short report: variation in mitochondrial $12 \mathrm{~S}$ and $16 \mathrm{~S}$ ribosomal DNA sequences in natural populations of Triatoma infestans (Hemiptera: Reduviidae). Am J Trop Med Hyg 68: 692-694.

García BA, Zheng LB, De Rosas ARP and Segura EL. 2004. Isolation and characterization of polymorphic microsatellite loci in the Chagas' disease vector Triatoma infestans (Hemiptera: Reduviidae). Mol Ecol Notes 4: 568-571.

Gaunt MW and Miles MA. 2002. An insect molecular clock dates the origin of the insects and accords with palaeontological and biogeographic landmarks. Mol Biol Evol 19: 748-761.

Gorla DE, Jurberg J, Catalá SS and Schofield CJ. 1993. Systematics of Triatoma sordida, T. guasayana and T. patagonica (Hemiptera, Reduviidae). Mem Inst Oswaldo Cruz 88: 379-385.

Guhl F ANd Schofield CJ. 1996. Population genetics and control of Triatominae. Parasitol Today 12: 169 170.

Guhl F And Schofield CJ (Eds). 2004. Proceedings of the ECLAT-AMCHA International Workshop on Chagas disease surveillance in the Amazon Region. CIMPAT-Universidad de los Andes, Bogotá, Colombia, $174 \mathrm{p}$.

HARRY M. 1993. Isozymic data question the specific status of some blood-sucking bugs of the genus Rhodnius, vectors of Chagas disease. Trans R Soc Trop Med Hyg 87: 492-493.

Harry M Galíndez Girón I ANd Cariou ML. 1992a. Isozyme variability and differentiation between Rhodnius prolixus, $R$. robustus and R. pictipes, vectors of Chagas disease in Venezuela. Med Vet Entomol 6: 37-43.
Harry M, Moreno G and Goyffon M. 1992b. Genetic variability in populations of Rhodnius prolixus, vector of Chagas disease in Venezuela. Evol Biol 6: 175-194.

Harry M, Poyet G, Romaña CA and Solignac M. 1998. Identification and characterization of microsatellite markers in the bloodsucking bug Rhodnius pallescens (Heteroptera, Reduviidae). Mol Ecol 7: 1784-1786.

Hillis DM, Moritz C and Mable BK. 1996. Molecular Systematics, Massachusetts: Sinauer Associates, $655 \mathrm{p}$.

Hypša V, Tietz DF, Zrzavý J, Rego ROM, Galvão C AND JURBerg J. 2002. Phylogeny and biogeography of Triatominae (Hemiptera: Reduviidae): molecular evidence of a New World origin of the Asiatic clade. Mol Phylogenet Evol 23: 447-457.

Jaramillo C, Montaña MF, Castro LR, Vallejo GA AND GuHL F. 2001. Differentiation and genetic analysis of Rhodnius prolixus and Rhodnius colombiensis by rDNA and RAPD amplification. Mem Inst Oswaldo Cruz 96: 1043-1048.

JaRne P AND Lagoda PJL. 1996. Microsatellites, from molecules to populations and back. Trends Ecol Evol 11: 424-429.

JURBERG J. 1996. Uma abordagem filogenética entre os triatomíneos baseada nas estruturas fálicas. In: ProCEEDINGS OF THE INTERNATIONAL WORKSHOP ON Population Genetics and Control of TriatomiNAE, Santo Domingo de los Colorados, Ecuador. INDRE Mexico City: C. J. Schofield, J. B. Dujardin and J. Jurberg, p. 51-52.

Jurberg J, Galvão C, Lent H, Monteiro F, Lopes CM, Panzera F And Pérez R. 1998. Revalidação de Triatoma garciabesi Carcavallo, Cichero, Martínez, Prosen and Ronderos, 1967 (Hemiptera-Reduviidae). Entomol Vect 5: 107-122.

Lent H And Wygodzinsky P. 1979. Revision of the Triatominae (Hemiptera: Reduviidae), and their significance as vectors of Chagas disease. Bull Am Mus Nat His 163: 123-520.

Li W-H AND Graur D. 1991. Fundamentals of Molecular Evolution, Massachusetts: Sinauer Associates, $284 \mathrm{p}$.

LoxdAle HD AND Lushai G. 1998. Molecular markers in entomology. Bull Entomol Res 88: 577-600. 
Lyman DF, Monteiro FA, Escalante AA, CordónRosales C, Wesson DM, Dujardin JP AND BeArD CB. 1999. Mitochondrial DNA sequence variation among triatomine vectors of Chagas disease. Am J Trop Med Hyg 60: 377-386.

Marcilla A, Canese N, Acosta E, López A, Rojas de Arias A, Bargues MD and Mas-Coma S. 2000. Populations of Triatoma infestans (Hemiptera: Reduviidae) from Paraguay: a molecular analysis based on the second internal transcribed spacer of the rDNA. Res Rev Parasitol 60: 99-105.

Marcilla A, Bargues MD, Ramsey JM, MagallónGastélum E, Salazar-Schettino PM, AbadFranch F, Dujardin JP, Schofield CJ AND MasComa S. 2001. The ITS-2 of the nuclear rDNA as a molecular marker for populations, species, and phylogenetic relationships in Triatominae (Hemiptera: Reduviidae), vectors of Chagas disease. Mol Phylogenet Evol 18: 136-142.

Marcilla A Et AL. 2002. Nuclear rDNA ITS-2 sequences reveal polyphyly of Panstrongylus species (Hemiptera: Reduviidae: Triatominae), vectors of Trypanosoma cruzi. Infect Genet Evol 1: 225-235.

Miles MA, Feliciangeli MD AND Arias AR. 2003. American trypanosomiasis (Chagas' disease) and the role of molecular epidemiology in guiding control strategies. Brit Med J 28: 1444-1448.

Monteiro FA, Costa J and Solé-Cava AM. 1998. Genetic confirmation of the specific status of Triatoma petrochii (Hemiptera: Reduviidae: Triatominae). Ann Trop Med Parasitol 92: 897-900.

Monteiro FA, Pérez R, Panzera F, Dujardin JP, Galvão C, Rocha D, Noireau F, Schofield CJ AND BEARD CB. 1999. Mitochondrial DNA variation of Triatoma infestans populations and its implication on the specific status of T. melanosoma. Mem Inst Oswaldo Cruz 94 (Suppl. 1): 229-238.

Monteiro FA, Wesson DM, Dotson EM, Schofield CJ AND BEARD CB. 2000. Phylogeny and molecular taxonomy of the Rhodniini derived from mitochondrial and nuclear DNA sequences. Am J Trop Med Hyg 62: 460-465.

Monteiro FA, Escalante AA and Beard CB. 2001. Molecular tools and triatomine systematics: a public health perspective. Trends Parasitol 17: 344-347.

Monteiro FA, Lazoski C, Noireau F and SoléCava AM. 2002. Allozyme relationships among ten species of Rhodniini, showing paraphyly of Rhodnius including Psammolestes. Med Vet Entomol 16: 83-90.

Monteiro FA, Barrett TV, Fitzpatrick S, CordónRosales C, Feliciangeli D and Beard CB. 2003. Molecular phylogeography of the Amazonian Chagas disease vectors Rhodnius prolixus and $R$. robustus. Mol Ecol 12: 997-1006.

Monteiro FA, Donnelly MJ, Beard CB and Costa J. 2004. Nested clade and phylogeographic analyses of the Chagas disease vector Triatoma brasiliensis in Northeast Brazil. Mol Phylogenet Evol 32: 46-56.

Morel CM and Lazdins J. 2003. Chagas disease. Nature Rev Microbiol 1: 14-15.

Moreno MJ, Galvão C and Jurberg J. 1999. Rhodnius colombiensis sp. $\mathrm{n}$. da Colômbia, com quadros comparativos entre estruturas fálicas do gênero Rhodnius Stål, 1859 (Hemiptera, Reduviidae, Triatominae). Entomol Vect 6: 601-617.

NeI M. 1972. Genetic distance between populations. Am Nat 106: 283-292.

NoIreau F AND Dujardin JP. 2001. Flight and nutritional status of sylvatic Triatoma sordida and $T$. guasayana. Mem Inst Oswaldo Cruz 96: 385-389.

Noireau F, Flores R, Gutiérrez T and Dujardin JP. 1997. Detection of wild dark morphs of Triatoma infestans in the Bolivian Chaco. Mem Inst Oswaldo Cruz 92: 583-584.

Noireau F, Gutiérrez T, Zegarra M, Flores R, BreNIÉRE SF, Cardozo L and Dujardin JP. 1998. Cryptic speciation in Triatoma sordida (Hemiptera: Reduviidae) from the Bolivian Chaco. Trop Med Int Health 3: 364-372.

Noireau F, Gutiérrez T, Flores R, Breniére SF, Bosseno MF AND Wisnivesky-Colli C. 1999a. Ecogenetics of Triatoma sordida and Triatoma guasayana (Hemiptera: Reduviidae) in the Bolivian Chaco. Mem Inst Oswaldo Cruz 94: 451-457.

Noireau F, Zegarra M, OrdóÑEZ J, Gutiérrez T AND Dujardin JP. 1999b. Genetic structure of Triatoma sordida (Hemiptera: Reduviidae) domestic populations from Bolivia: application on control interventions. Mem Inst Oswaldo Cruz 94: 347-351.

Noireau F, Bastrenta B, Catalá SS, Dujardin JP, Panzera F, Torres M, Pérez R, Jurberg J and GAlvão C. 2000a. Sylvatic population of Triatoma infestans from the Bolivian Chaco: from field col- 
lection to characterization. Mem Inst Oswaldo Cruz 95: 119-122.

Noireau F, Flores R, Gutiérrez T, Abad-Franch F, Flores E AND Vargas F. 2000b. Natural ecotopes of Triatoma infestans dark morph and other sylvatic triatomines in the Bolivian Chaco. Trans R Soc Trop Med Hyg 94: 23-27.

Noireau F, dos Santos SM, Gumiel M, Dujardin JP, Soares MS, Carcavallo RU, Galvão C and JuRBERG J. 2002. Phylogenetic relationships within the oliveirai complex (Hemiptera: Reduviidae: Triatominae). Infect Genet Evol 2: 11-17.

Noireau F, Cortez MG, Monteiro FA, Jansen AM AND ToRrico F. 2005. Can wild Triatoma infestans foci in Bolivia jeopardize Chagas disease control efforts? Trends Parasitol 21: 7-10.

Pacheco RS, Almeida CE, Costa J, Klisiowicz DR, Mas-Coma S ANd BARgues MD. 2003. RAPD analyses and rDNA intergenic-spacer sequences discriminate Brazilian populations of Triatoma rubrovaria (Reduviidae: Triatominae). Ann Trop Med Parasitol 97: 757-768.

Page RDM and Holmes E. 1998. Molecular evolution. Blackwell Science, London, UK, 346 p.

Panzera F, Hornos S, Pereira J, Cestau R, Canale D, Diotaiuti L, Dujardin JP and Pérez R. 1997. Genetic variability and geographic differentiation among three species of triatomine bugs (Hemiptera: Reduviidae). Am J Trop Med Hyg 57: 732-739.

PANZERA F ET AL. 2004. Genomic changes of Chagas disease vector, South America. Emerg Infect Dis 10: $438-446$.

PATTERSON JS. 2002. An evaluation of comparative morphometrics of triatomine bugs (Hemiptera: Reduviidae) as a taxonomic tool, and as an indicator of genetic diversity and evolutionary history. MPhil-PhD Upgrading Report, LSHTM, London, UK, 100 p.

Pereira J, Dujardin JP, Salvatella R and Tibayrenc M. 1996b. Enzymatic variability and phylogenetic relatedness among Triatoma infestans, T. platensis, T. delpontei, and T. rubrovaria. Heredity 77: 47-54.

RAMSEy JM AND Schofield CJ. 2003. Control of Chagas disease vectors. Salud Públ Mex 45: 123-128.

Saccone C, Gissi C, Lanave C, Larizza A, Pesole G AND REYES. 2000. Evolution of the mitochondrial genetic system: an overview. Gene 261: 153-159.
Sainz AC, Mauro LV, Moriyama EN and García BA. 2004. Phylogeny of triatomine vectors of Trypanosoma cruzi suggested by mitochondrial DNA sequences. Genetica 121: 229-240.

Schaefer CW. 2003. Triatominae (Hemiptera: Reduviidae): systematic questions and some others. Neotrop Entomol 32: 1-9.

Schofield CJ ANd Dujardin JP. 1997. Chagas disease vector control in Central America. Parasitol Today 13: 141-144.

Schofield CJ, Dujardin JP and Jurberg J. 1995. Population Genetics of Triatominae: support for vigilance and control interventions. Mem Inst Oswaldo Cruz 90 (Suppl. 1): 57.

Simon C, Frati F, Beckenbach A, Crespi B, Liu H and FLOOK P. 1994. Evolution, weighting, and phylogenetic utility of mitochondrial gene sequences and a compilation of conserved Polymerase Chain Reaction primers. Ann Entomol Soc Am 87: 651-701.

Solano P, Dujardin JP, SCHOFIEld CJ, Romaña C AND Tibayrenc M. 1996. Isoenzymes as a tool for the identification of Rhodnius species. Res Rev Parasitol 56: $41-47$.

Stevens JR and Schofield CJ. 2003. Phylogenetics and sequence analysis - some problems for the unwary. Trends Parasitol 19: 582-588.

Stothard JR, Yamamoto Y, Cherchi A, García AL, Valente SAS, Schofield CJ ANd Miles MA. 1998. A preliminary survey of mitochondrial sequence variation within triatomine bugs (Hemiptera: Reduviidae) using polymerase chain reaction-based single strand conformational polymorphism (SSCP) analysis and direct sequencing. Bull Entomol Res 88: 553-560.

Thorpe JP And Solé-Cava AM. 1994. The use of allozyme electrophoresis in invertebrate systematics. Zool Scripta 23: 3-18.

WHO. 1991. Control of Chagas disease. WHO Technical Report Series 811: 95.

WHO. 2002. Control of Chagas disease. Second Report of the WHO Expert Committee. WHO Technical Report Series 905: 109.

WORLD BANK. 1993. World development report 1993. Investing in health. Oxford University Press, New York, NY, USA, 329 p. 